\title{
Correction to: The Childbirth Environment and Parenthood: Time, Pain, and Subjective Constitution
}

\section{Mariana Gouvêa de Matos $^{1} \cdot$ Andrea Seixas Magalhães $^{2} \cdot$ Mayla Cosmo $^{1}$ • Terezinha Féres-Carneiro ${ }^{2}$}

Published online: 14 December 2020

(C) Associação Brasileira de Psicologia 2020

\section{Correction to: Trends in Psychology \\ https://doi.org/10.1007/s43076-020-00045-z}

This article was originally published with its main title in Portuguese, so it was updated with the main title in English. The original article has been corrected.

The online version of the original article can be found at https://doi.org/10.1007/s43076-020-00045-z

Mariana Gouvêa de Matos

mariana.g.matos@hotmail.com

1 Clinical Psychology, Pontifical Catholic University of Rio de Janeiro, Largo doMachado, 29/522, Catete, Rio de Janeiro RJ CEP22240-000, Brazil

2 Pontifical Catholic University of Rio de Janeiro, Rio de Janeiro, Brazil 